Merpiseldin Nitsae, Armeida Madjid, Lukman Hakim and Akhmad Sabarudin

\title{
PREPARATION OF CHITOSAN BEADS USING TRIPOLYPHOSPHATE AND ETHYLENE GLYCOL DIGLYCIDYL ETHER AS CROSSLIN KER FOR Cr(VI) ADSORPTION
}

\author{
Department of Chemistry, Faculty of Science, Brawijaya University, \\ J I. Veteran 65145, M alang, East J ava, Indonesia; sabarjpn@ ub.ac.id
}

Received: July 29, 2015 / Revised: September 23, 2015 / Accepted: December 02, 2015

(c) Nitsae M., Madjid A., Hakim L., Sabarudin A., 2016

\begin{abstract}
A solid-phase material based on modified chitosan using tripolyphosphate (TPP) and ethylene glycol diglycidyl ether (EGDE) as a crosslinker has been prepared, and its ability in adsorbing $\mathrm{Cr}(\mathrm{VI})$ has been examined. In this work, a chitosan flake was shaped into beads using TPP, and its chemical stability was improved through reaction with EGDE as the crosslinker. Some parameters that may influence the product, such as composition and immersion time, were systematically studied to obtain the optimum conditions. The obtained material was characterized using SEM and FT-IR. The ability of the modified chitosan for the $\mathrm{Cr}(\mathrm{VI})$ adsorption was described by the adsorption capacity and kinetics study. The results showed that the modified chitosan has $\mathrm{Cr}(\mathrm{VI})$ adsorption capacity of $104.283 \mathrm{mg} \cdot \mathrm{g}^{-1}$ at $\mathrm{pH}=3$, and the adsorption follows the first-order rate, suggesting an ion-exchange mechanism which is responsible for this interaction.
\end{abstract}

Keywords: chitosan beads, $\mathrm{Cr}(\mathrm{VI})$, tripolyphosphate, adsorption capacity, adsorption kinetics.

\section{Introduction}

The presence of chromium in aquatic environment provides a negative impact on plants, animals, aquatic organisms and especially on humans $[1,2]$. The toxicity of chromium depends on its oxidation level, for example chromium as $\mathrm{Cr}(\mathrm{VI})$ is carcinogenic and mutagenic substance. Species of $\mathrm{Cr}(\mathrm{VI})$ ions pass through a membrane cell in the form of $\mathrm{CrO}_{4}{ }^{2-}$ and $\mathrm{HCrO}_{4}{ }^{-}[3,4]$. A lot of researches have been done to reduce heavy metal ions by using various methods such as separation methods, electro-chemical treatments, bioremidiation and adsorption $[1,5]$. Adsorption is the process of substance accumulation on a surface can be influenced by physical and chemical parameters of adsorbent and adsorbate such as temperature, $\mathrm{pH}$, concentration, pressure, and contact time [3]. Generally, activated carbon [6], silica [7], and biomass [8] were used to adsorb heavy metals. Xin-Jiang $\mathrm{Hu}$ et al. [8] reported that the adsorption of $\mathrm{Cr}(\mathrm{VI})$ ions using biomass was influenced by $\mathrm{pH}$ and temperature. It was found that at high $\mathrm{pH}(>3)$ the adsoption capacity of $\mathrm{Cr}(\mathrm{VI})$ ions is low due to the change of $\mathrm{HCrO}_{4}^{-}$species into other forms such as $\mathrm{Cr}_{2} \mathrm{O}_{7}{ }^{2-}$ and $\mathrm{CrO}_{4}{ }^{2-}$.

Chitosan (poly( $\beta-1-4)-2$-amino-2-deoxy-D-glucopyranose) is one of abundant adsorbent biopolymers which has two functional groups: amino $\left(-\mathrm{NH}_{2}\right)$ and hydroxyl $(-\mathrm{OH})$ groups $[2,9]$. The functional groups have the ability to adsorb many substances such as proteins, dyes and heavy metals [10]. Nevertheless, chitosan has poor chemical stability because it may dissolve in acidic solution such as acetic acid $\left(\mathrm{CH}_{3} \mathrm{COOH}\right)$, nitric acid $\left(\mathrm{HNO}_{3}\right)$ and hydrochloric acid $(\mathrm{HCl})$. Hence, its application is limited and chitosan needs to be modified to improve its chemical stability and adsorption capabilities.

Chitosan can be physically and chemically modified in order to reduce the particle size, increase surface area and adsorption. Moreover, the stability of chitosan can be improved through chemical modification by adding the crosslinking agents such as ethylene glycol diglycidyl ether (EGDE), epichlorohydrin (ECH), glutaraldehyde (GLA) or tripolyphosphate (TPP) [11]. The results of chitosan modification are beads, flakes and membranes. Chitosan beads could be obtained by dissolving chitosan in acetic acid followed by treating with TPP or $\mathrm{NaOH}$ [12]. Chitosan beads with an uniform shape can be used in a flow system to adsorb heavy metals [13]. 
According to $[10,14]$, TPP is used as a crosslinking agent because this compound is a polianion which reacts with chitosan by means of electrostatic forces. Amine groups in chitosan interact with a negative charge on TPP by ionic bonding to form crosslinking networks. Besides as a crosslinking agent, TPP is also useful to maintain the shape of the chitosan beads. Meanwhile, Fwu-Long Min et al. [9] used EGDE as a crosslinking agent because it can produce an appropriate pore size for the adsorption of metal ions.

Furthermore, the aim of this study is to produce modified chitosan using TPP to form the chitosan beads and to use crosslinking agent EGDE to increase the adsorption capacity of $\mathrm{Cr}(\mathrm{VI})$ ions.

\section{Experimental}

\subsection{M aterials and Reagents}

Chitosan with high molecular weight, sodiumtripolyphosphate (TPP) and ethylene glycol diglycidyl ether (EGDE) were purchased from Sigma-Aldrich; potassium dichromate $\left(\mathrm{K}_{2} \mathrm{Cr}_{2} \mathrm{O}_{7}\right)$ was purchased from Merck. All used reagents were of analytical-reagent grade. Deionized water was used throughout the study.

\subsection{Preparation of Chitosan Beads}

Chitosan solution $1 \%(\mathrm{w} / \mathrm{v})$ was prepared by dissolving $1 \mathrm{~g}$ of chitosan in $100 \mathrm{ml}$ of $5 \%(\mathrm{v} / \mathrm{v})$ acetic acid. The solution was strirred for $1 \mathrm{~h}$ and left overnight. Then, chitosan solution was dropped into $1 \%(\mathrm{w} / \mathrm{v})$ TPP to produce chitosan beads. The chitosan beads were immersed for $3 \mathrm{~h}$ and filtered to separate the chitosan beads from TPP solution. Furthermore, the chitosan beads reacted and were immersed in $5 \%(\mathrm{v} / \mathrm{v})$ EGDE for $3 \mathrm{~h}$ at 323-333 K to produce chitosan:TPP:EGDE beads. After that, $\mathrm{NaOH}(\mathrm{pH} \geq 10)$ was added and left for $1 \mathrm{~h}$ to neutralize as well as to allow removal of TPP from chitosan networks. Finally, the crosslinked chitosan beads were filtered, washed with deionized water and dried at 373-378 K. In this study, various concentrations of TPP $(5,10$ and $15 \%)$, immersion time, and also composition of EGDE were studied in details.

Characterization of chitosan beads was done using FT-IR and scanning electrone microscope (SEM). The $\mathrm{Cr}(\mathrm{VI})$ adsorption ability of chitosan beads were investigated by adsorption kinetics using fractionation time and Powell plot methods.

\subsection{Parameters Optimization for the Adsorption of $\mathrm{Cr}(\mathrm{VI})$ Ion onto Chitosan Beads}

Adsorption of $\mathrm{Cr}(\mathrm{VI})$ onto chitosan beads was examined using a batch method, in which $0.02 \mathrm{~g}$ of chitosan beads was equilibrated with $50 \mathrm{ml}$ of $20 \mathrm{mg} / 1$ $\mathrm{Cr}(\mathrm{VI})$ solution and shaked at $100 \mathrm{rpm}$ for $2 \mathrm{~h}$. After the adsorption process, $0.25 \mathrm{ml}$ of $0.5 \%$ diphenylcarbazide was added into $0.25 \mathrm{ml}$ of $\mathrm{Cr}(\mathrm{VI})$ solution and $\mathrm{pH}$ of solution was adjusted by adding $\mathrm{H}_{2} \mathrm{SO}_{4}$ solution to reach $\mathrm{pH}=2$. Then the solution was diluted in $25 \mathrm{ml}$ volumetric flask. The absorbance was measured using UV-Vis spectrophotometer Shimadzu Genesis 105. Some parameters affecting the adsorption efficiency were studied, which include optimization of $\mathrm{pH}(\mathrm{pH}=2-7)$, and contact time between $\mathrm{Cr}(\mathrm{VI})$ ions and chitosan beads to find out the equilibrium adsorption capacity and analyze the adsorption kinetics.

\subsection{Characterization of Chitosan Beads}

The chitosan beads (chitosan-TPP-EGDE) with the highest adsorption capacity were characterized using a scanning electron microscope (SEM) Hitachi TM 3000 to discover surface morphology and the pore size of the chitosan beads. Additionally, chitosan beads were also examined using infra-red spectrophotometer (FT-IR 8400) to determine existing functional groups in each step modification of chitosan beads.

\subsection{Determination of Adsorption Capacity and Kinetic Models}

The adsorption capacity, $q_{e}$, of each optimization stage was calculated using the following equation:

$$
q_{e}=\left(\frac{C_{0}-C_{e}}{W}\right) \cdot V
$$

where $C_{0}$ and $C_{e}$ are the initial and final concentrations of $\mathrm{Cr}(\mathrm{VI})$ ions, respectively, $\mathrm{mg} \mathrm{l}^{-1} ; V$ is the solution volume, $1 ; W$ is the weight of the chitosan beads used, $\mathrm{g}$.

For determination of adsorption kinetics, two different methods such as fractionation time $t_{\alpha}$ and Powell plot method were employed. These methods were also used to determine the reaction order $n$ and adsorption rate constant $k_{a}$.

\section{Results and Discussion}

\subsection{Preparation of Chitosan Beads}

Chitosan has been modified through three stages. First, TPP is used to form the beads and acts as the protecting group of $-\mathrm{NH}_{2}$ in the chitosan (Fig. 1a.). In this case, negatively charged phosphate group in TPP interacts with protonated amine groups of chitosan through the electrostatic bonding. Second, EGDE is added as a crosslinking agent (Fig. 1c). Generally, the epoxide groups of EGDE bound to the amine groups $\left(-\mathrm{NH}_{2}\right)$, however in this work, the epoxy groups react with the hydroxyl group $(-\mathrm{OH})$ of chitosan due to the formation of ionic bonding of TPP with $-\mathrm{NH}_{2}$ groups. The crosslinking 
reaction may increase the chemical stability of chitosan beads. Protected amine groups act as active groups leading the chitosan beads to be used as an adsorbent. However, the crosslinker EGDE may reduce the active group of chitosan beads so that the adsorption capacity possibly decreases. Third, $\mathrm{NaOH}$ is added until $\mathrm{pH} \geq 10$ to neutralize and remove TPP (Fig 1d), providing free $-\mathrm{NH}_{2}$ groups of chitosan as the active binding sites for metal ions. A chitosan beads were dried in an oven at the temperature above $373 \mathrm{~K}$ (Fig. 1f).

In this study, the resulted chitosan beads are not uniform (Fig. 2). This figure shows the morphology of chitosan beads under optimum conditions (5\% TPP, $5 \%$ EGDE and $3 \mathrm{~h}$ immersion time). The surface morphology of chitosan beads possesses macropore structures, in which the pores are interconnected with each other. Pore size of the resulted chitosan beads was 15-24 $\mu \mathrm{m}$ and diameter of the chitosan beads was in the range of 509-529 $\mu \mathrm{m}$. The produced chitosan beads were rigid, increasing the stability of their structure, whereas their pores may be responsible for the adsorption of substances of interest.
Examination of chitosan beads using FT-IR (Fig. 3) was conducted to distinguish the existing functional groups in the formed chitosan beads before and after modification. As it can be seen, the peak at $3417 \mathrm{~cm}^{-1}$ appears as a result of the stretching vibration of $-\mathrm{OH}$ groups. Then, due to the addition of other compounds, vibration is shifted to a broader peak at $3421 \mathrm{~cm}^{-1}$. Furthermore, when the chitosan was changed into chitosan beads, there is a peak shifted from 1662 to $1558 \mathrm{~cm}^{-1}$, indicating the presence of $\mathrm{NH}_{3}{ }^{+}$groups. The peak at $1541 \mathrm{~cm}^{-1}$, which is ascertained by existence of the peak at $1155 \mathrm{~cm}^{-1}$, confirms the vibration of $\mathrm{P}=\mathrm{O}$ group of TPP. Peak at $1261 \mathrm{~cm}^{-1}$ shows stretching vibration of $\mathrm{C}=\mathrm{O}$ group and the peak at $2923 \mathrm{~cm}^{-1}$ is attributed to $-\mathrm{CH}$ stretching vibration of alkanes $\left(-\mathrm{CH} s p^{3}\right)$, which is an additional important vibration. The IR spectra of the chitosan and the chitosan beads actually are almost similar. The differences are indicated by the reduction of the peak intensity of the highest peak at $3700-3200 \mathrm{~cm}^{-1}$ and the peak at $1400-1300 \mathrm{~cm}^{-1}$, corresponding to the interaction of chitosan with EGDE and TPP.
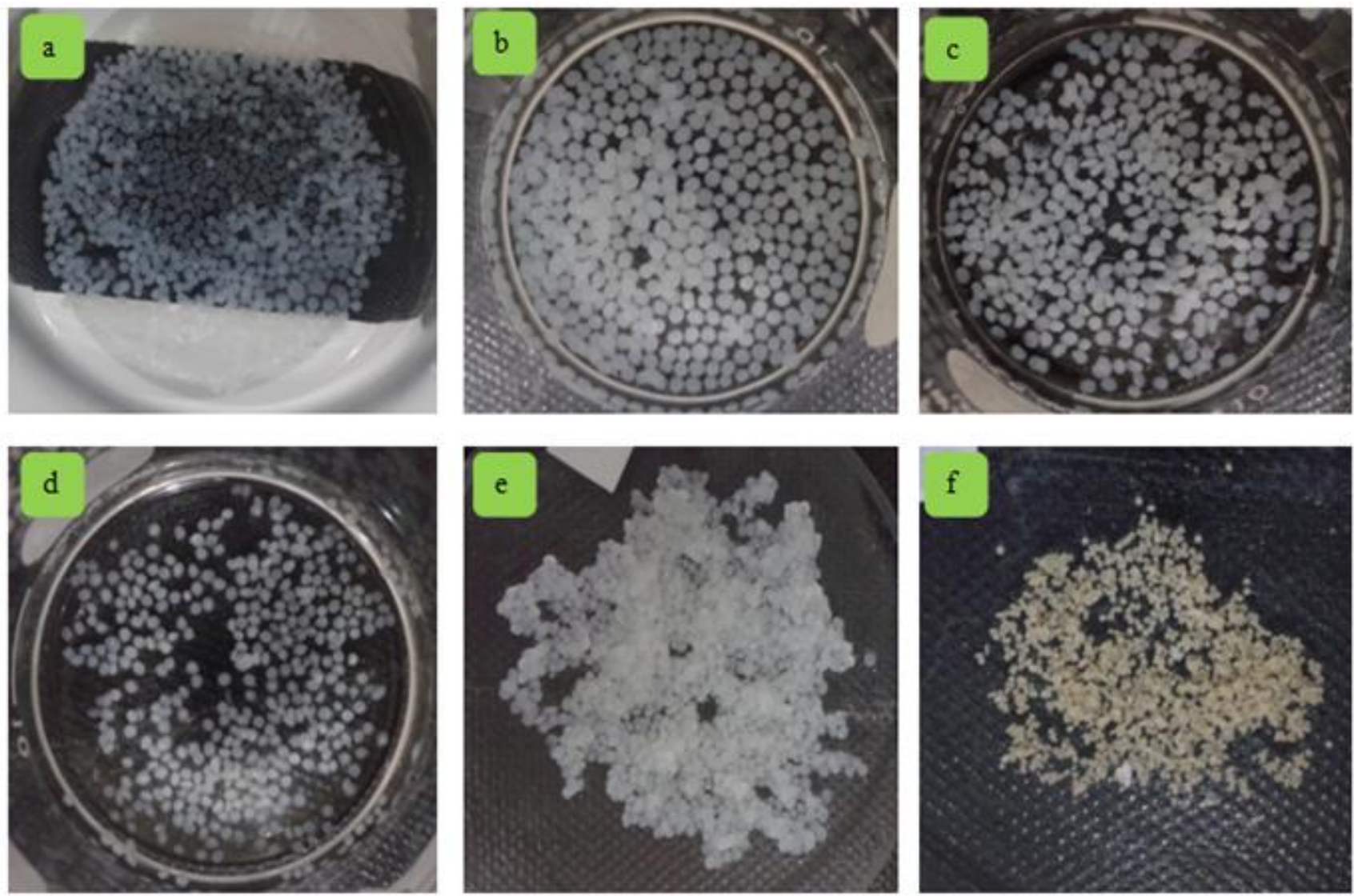

Fig. 1. Preparation of chitosan beads: chitosan in TPP (initial) (a); beads after immersion for $3 \mathrm{~h}$ in TPP (b); chitosan beads after EGDE addition (c); $\mathrm{NaOH}$ was added to beads after heating for $3 \mathrm{~h}$ at 323-333 $\mathrm{K}$ (d); beads are filtered after an immersion for $1 \mathrm{~h}$ (e) and resulted chitosan beads after heating at $373 \mathrm{~K}$ for $\pm 30 \mathrm{~min}$ (f) 

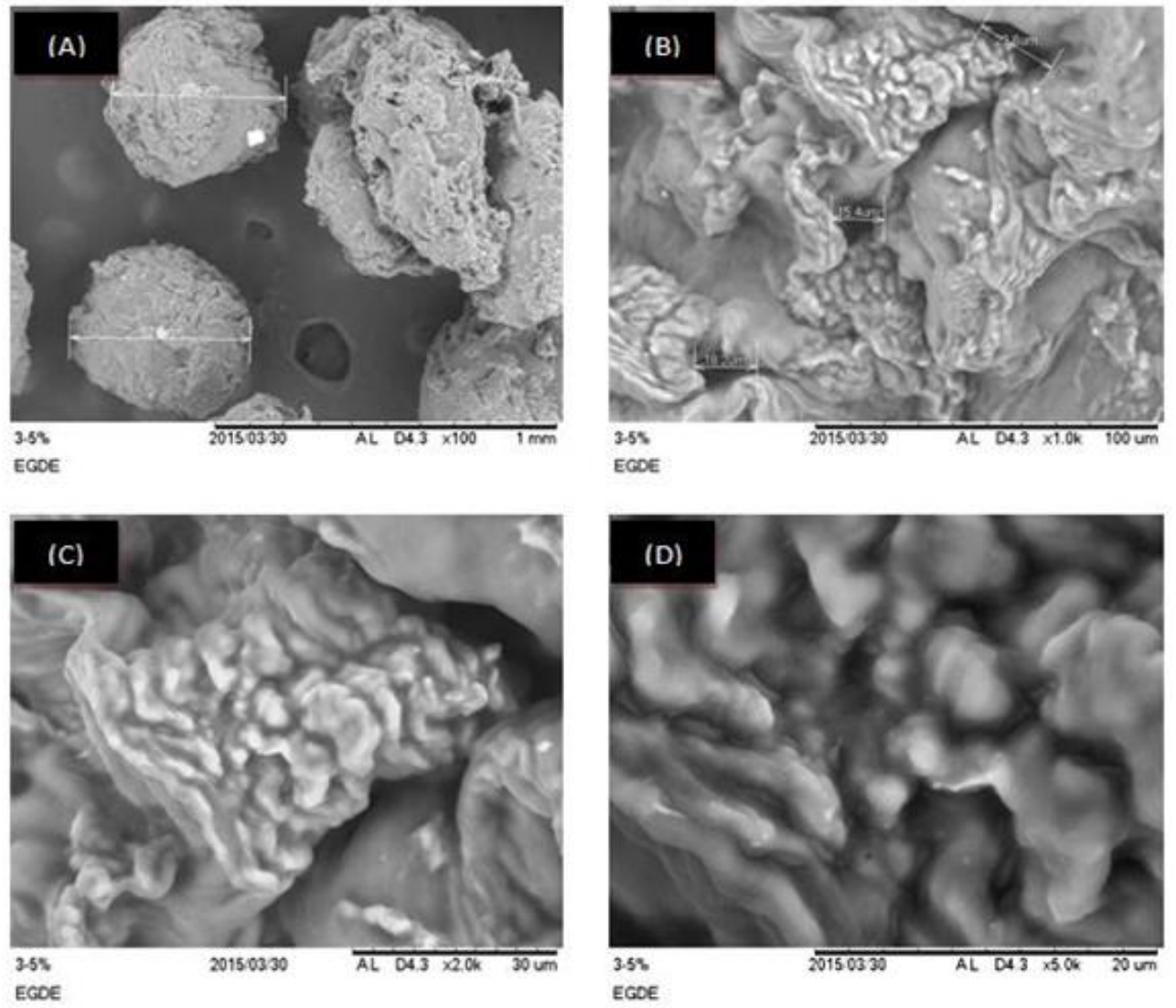

Fig. 2. SEM micrographs of chitosan beads under the optimum conditions ( $5 \% \mathrm{TPP}$, $5 \%$ EGDE, $3 \mathrm{~h}$ immersion time). Magnification of $100 \times(\mathrm{a}) ; 1000 \times(\mathrm{b}) ; 2000 \times(\mathrm{c})$ and $5000 \times(\mathrm{d})$

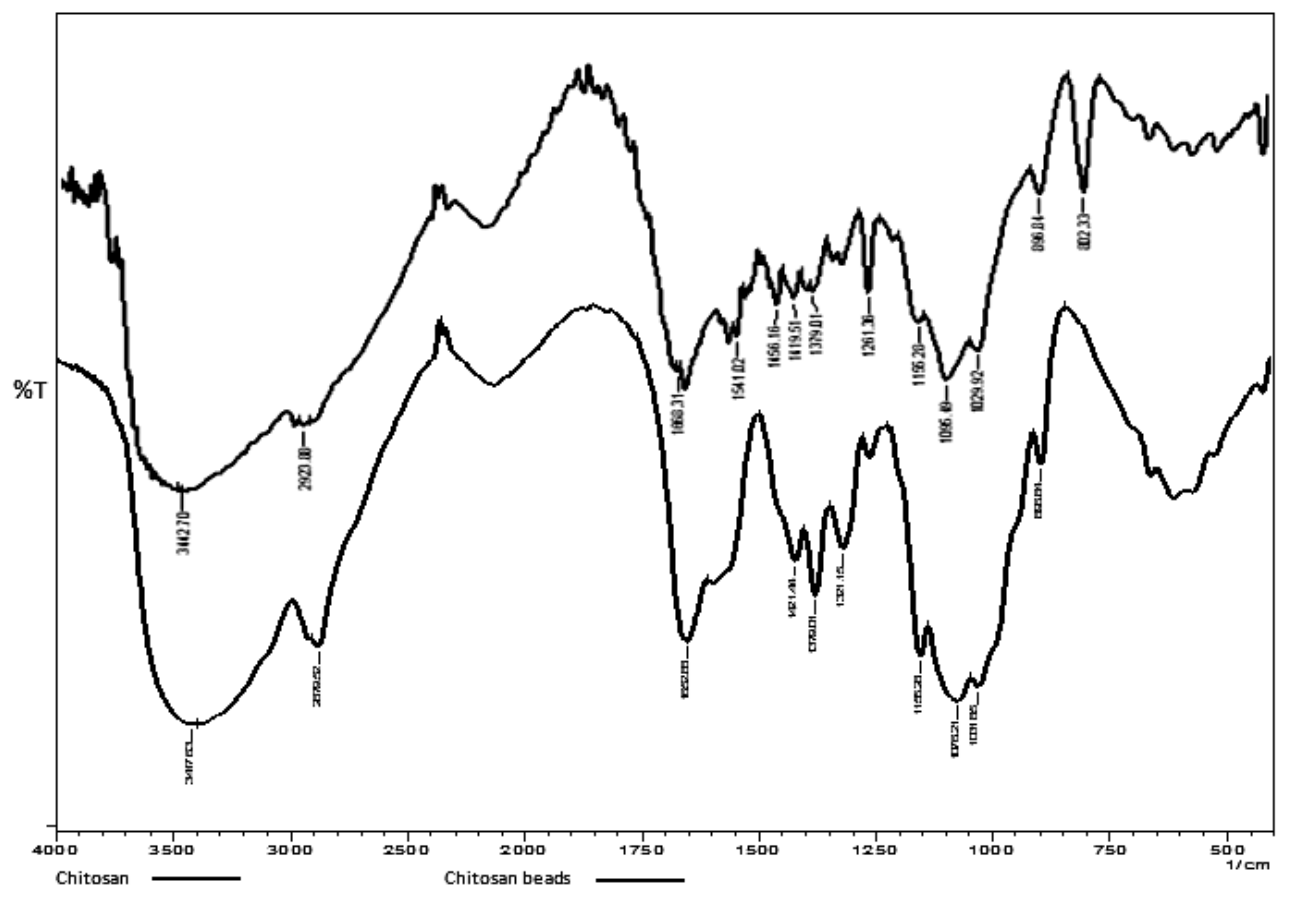

Fig. 3. FT-IR spectra of chitosan (lower) and chitosan bead (upper) 


\subsection{Concentration Effects}

\section{of Tripolyphosphate (TPP) and Ethylene Glycol Diglycidyl Ether (EGDE)}

TPP concentration strongly affects the formation of chitosan beads. Accordingly, it is very important to study the effect of TPP concentration. It was found that at the concentration of $1 \% \mathrm{TPP}$, the chitosan solution, which is dropped into TPP, forms beads immediately and then directly sinks at the bottom of the container. But, when the concentration of TPP is increased, the formed beads sink after a long time (immersing time). It seems that at the same concentration of TPP $(1 \% \mathrm{w} / \mathrm{v})$ with chitosan $(1 \% \mathrm{w} / \mathrm{v})$, their interaction occurrs very fast and hence it is easier to form beads. Meanwhile, at higher concentration of TPP, chitosan requires a long time to interact with TPP. As the result, at higher TPP concentrations $(5-15 \%)$ the formed beads tend to form clusters.
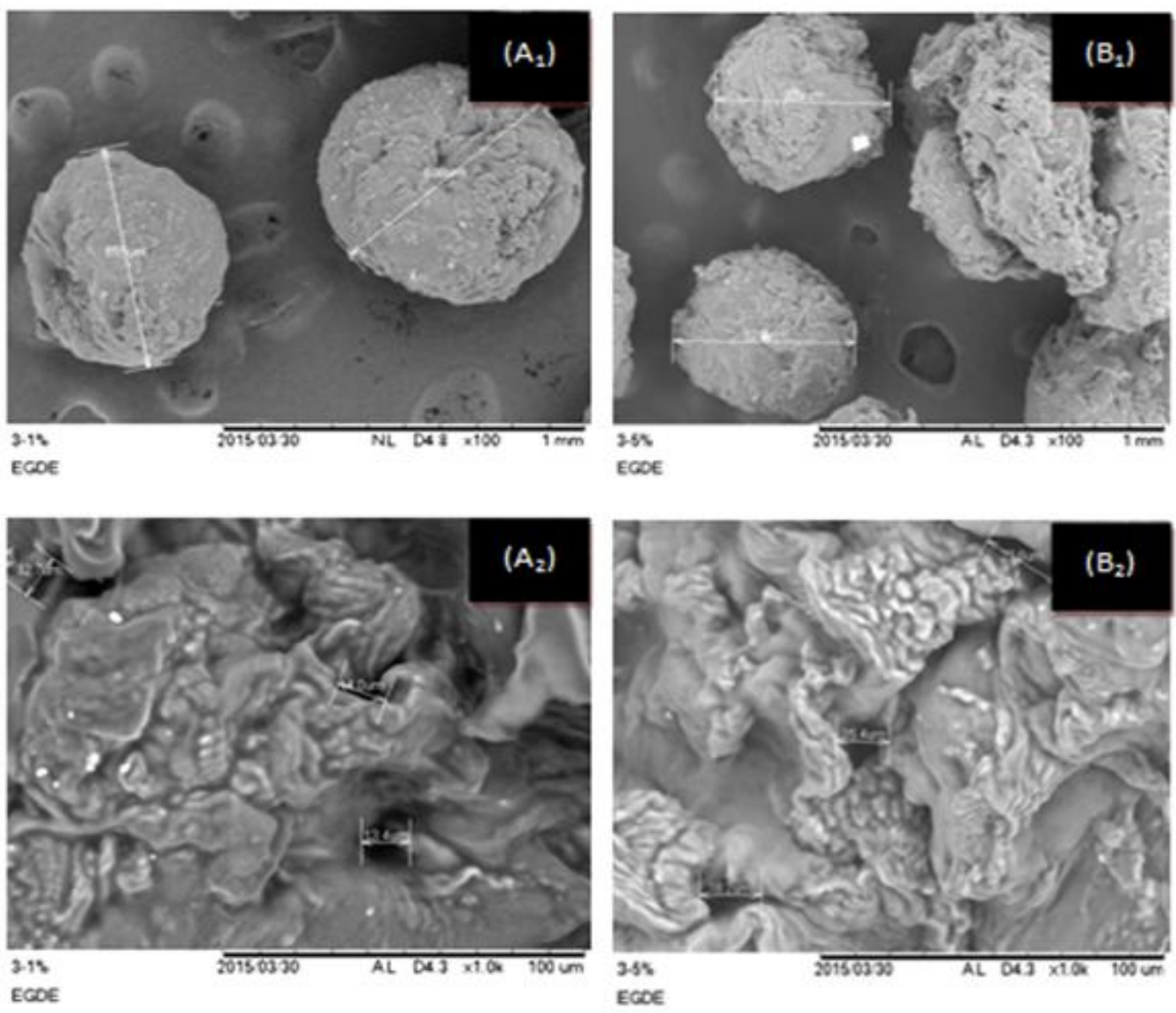

Fig. 5. SEM images of chitosan beads at different TPP concentration for $3 \mathrm{~h}$ immersion time: $1 \%$ TPP, magnification of $100 \times(\mathrm{a} 1)$ and $1000 \times(\mathrm{a} 2) ; 5 \% \mathrm{TPP}$, magnification of $100 \times(\mathrm{b} 1)$ and $1000 \times(\mathrm{b} 2)$ 
The highest adsorption of $\mathrm{Cr}(\mathrm{VI})$ occurrs at $5 \%$ TPP solution (Fig. 4). Although the shape of formed beads at $1 \%$ TPP solution is better than 5\% TPP solution, however its adsorption ability toward $\mathrm{Cr}(\mathrm{VI})$ decreases. This is probably caused by the fact that the amount of pores and density of beads in $1 \%$ TPP solution are lower than formed beads in 5\% TPP solution. SEM images in Fig. 5 confirm this. We can see the morphological differences which are distinguised by pore size (slits) of $12-14 \mu \mathrm{m}$ of beads prepared in $1 \%$ TPP (Fig. 5a), while it is $15-23 \mu \mathrm{m}$ in $5 \%$ TPP (Fig. 5b). However, the diameter of beads in $1 \%$ TPP is larger $(655-685 \mu \mathrm{m})$ than in $5 \%$ TPP $(509-529 \mu \mathrm{m})$. From these results, it is clear that density of beads in $1 \%$ TPP is lower than in $5 \%$ TPP. We also examined higher TPP concentration $(>5 \%)$, and it was found that there is a decline in adsorption capacity for $\mathrm{Cr}(\mathrm{VI})$. Apparently, it is difficult to form beads when the amount of TPP is increased.

The immersion time of resulted chitosan beads in TPP solution is important to be studied because it affects the bead formation, as well as the adsorption capacity. Therefore, various immersion times of $1,3,6,12$, and $24 \mathrm{~h}$ were examined (Fig. 6). The optimum adsorption capacity for chitosan beads toward $\mathrm{Cr}(\mathrm{VI})$ is achieved at $3 \mathrm{~h}$ of immersion time. In an hour of immersion time, the beads are not perfectly formed which is indicated by the formation of chitosan flakes. For immersion time of $>3 \mathrm{~h}$, the active group of produced chitosan beads $\left(\mathrm{NH}_{3}{ }^{+}\right)$are more rigid, which results in less interaction of the beads with $\mathrm{Cr}(\mathrm{VI})$ ions.

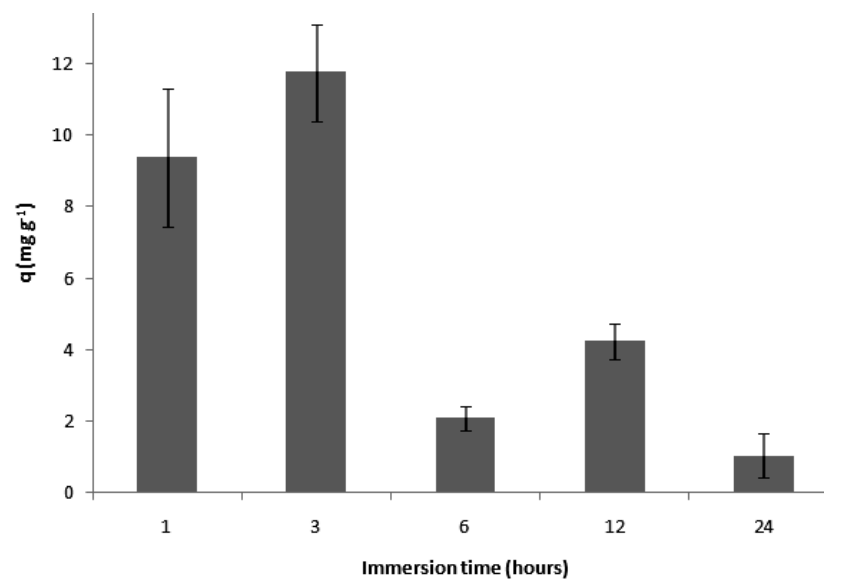

Fig. 6. The relationship between the immersion time and the amounts of $\mathrm{Cr}(\mathrm{VI})$ adsorbed onto chitosan beads

The amount of crosslinker (EGDE) may affect the adsorption capacity of the produced chitosan beads toward $\mathrm{Cr}(\mathrm{VI})$. As shown in Fig. 7, the optimum concentration of crosslinking agent is $5 \%$ EGDE as indicated by the highest adsorption amount of $\mathrm{Cr}(\mathrm{VI})$. When 1 and $2.5 \%$
EGDE are applied, the adsorbed $\mathrm{Cr}(\mathrm{VI})$ is probably weakly retained onto the beads, resulting in low adsorption capacity of this analyte. It seems that the pore size of beads is also responsible for the adsorption of $\mathrm{Cr}(\mathrm{VI})$. Larger pore size of beads is obtained at lower concentration of EGDE $(<5 \%)$, which is not fixed to the size of $\mathrm{Cr}(\mathrm{VI})$ ion. However, at higher concentration of EGDE $(>5 \%)$, all active sites of the produced chitosan beads are occupied by EGDE, so that the adsorption capacity of $\mathrm{Cr}(\mathrm{VI})$ is decreased.

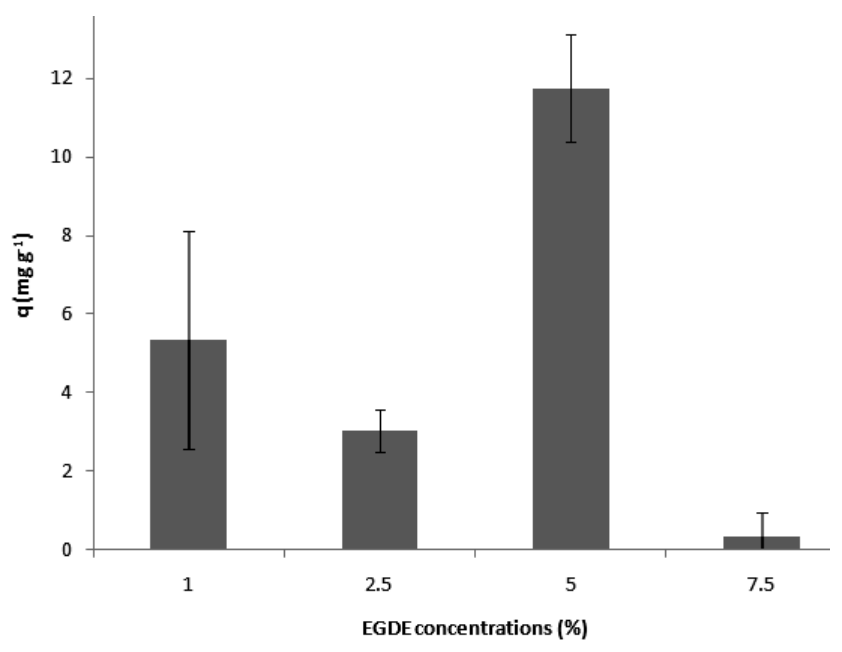

Fig. 7. The relationship between the EGDE concentration and the adsorbed amounts of $\mathrm{Cr}(\mathrm{VI})$ onto chitosan beads

\subsection{Effect of pH}

The adsorption of $\mathrm{Cr}(\mathrm{VI})$ onto chitosan beads is strongly influenced by acidity $(\mathrm{pH})$, as shown in Fig. 8 . This is due to the existence of $-\mathrm{NH}_{2}$ and $-\mathrm{OH}$ active groups in chitosan beads which could be covalently bonded with the other substance on certain conditions. At the $\mathrm{pH}<\mathrm{pKa}$ (6.5), chitosan beads can electrostatically interact with other negatively charged substances. Various $\mathrm{pH}$ values ( $\mathrm{pH} 2,3,4,5,6$, and 7) have been examined to determine the optimum $\mathrm{pH}$ in the adsorption of $\mathrm{Cr}(\mathrm{VI})$ within $2 \mathrm{~h}$ of contact time. At this $\mathrm{pH}$ range, amine groups of the chitosan beads are protonated into $\mathrm{NH}_{3}{ }^{+}$. On the contrary, $\mathrm{Cr}(\mathrm{VI})$ is present in the anionic forms. Therefore, anion exchange mechanism is responsible for the adsorption of $\mathrm{Cr}(\mathrm{VI})$ onto chitosan beads.

As shown in Fig. 8, the optimum adsorption of $\mathrm{Cr}(\mathrm{VI})$ is achieved at $\mathrm{pH}=3 . \mathrm{Cr}(\mathrm{VI})$ mainly exists in the form of $\mathrm{HCrO}_{4}^{-}$which is strongly bound with the positively single charged amine group $\left(\mathrm{NH}_{3}{ }^{+}\right)$in the chitosan beads. At $\mathrm{pH}=4-7$, the adsorption capacity decreases because two positive active sites of chitosan beads should be provided for species of $\mathrm{Cr}(\mathrm{VI})$ which have the charge of $-2\left(\mathrm{CrO}_{4}{ }^{2-}\right)$. Additionally, at $\mathrm{pH}>3$, 
the amount of the protonated amine group of chitosan beads decreases, which also contributes to the decrease in the adsorption amount of $\mathrm{Cr}(\mathrm{VI})$. At low $\mathrm{pH}$, the chitosan beads would easier protonate so that the negative charge of the other substances may interact with the chitosan beads and produce a higher adsorption capacity. Optimum $\mathrm{pH}$ is achieved at $\mathrm{pH}=3$ as indicated by the highest adsorption of $\mathrm{Cr}(\mathrm{VI})$ onto the beads.

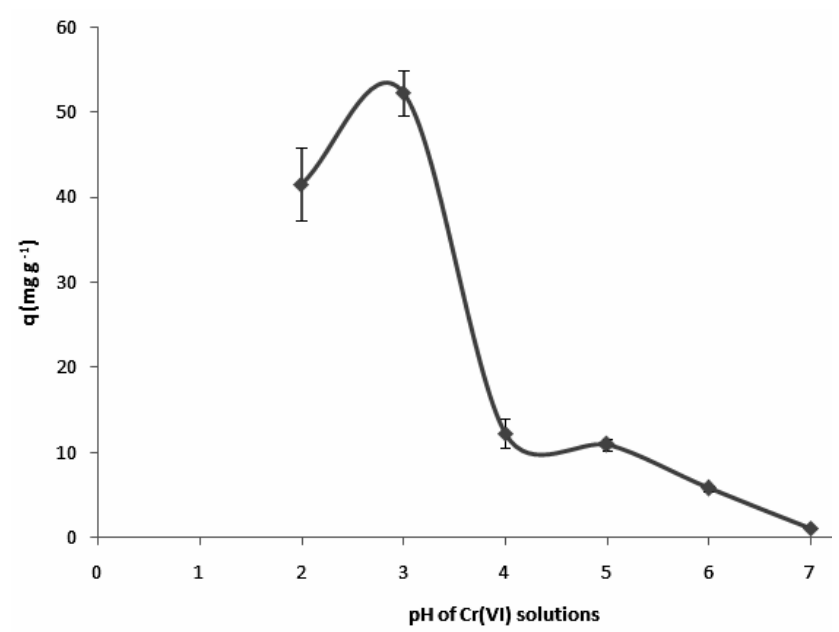

Fig. 8. Effect of $\mathrm{pH}$ on the adsorption of $\mathrm{Cr}(\mathrm{VI})$ onto chitosan beads

\subsection{Effect of the Contact Time between $\mathrm{Cr}(\mathrm{VI})$ and the Chitosan Beads}

The adsorption capacity of chitosan beads increases per unit of time and will reach the equilibrium at appropriate time. The equilibrium point is the condition, under which the adsorbent does not have any remaining active site to adsorb substances or metals. The optimum contact time is displayed in Fig. 9.

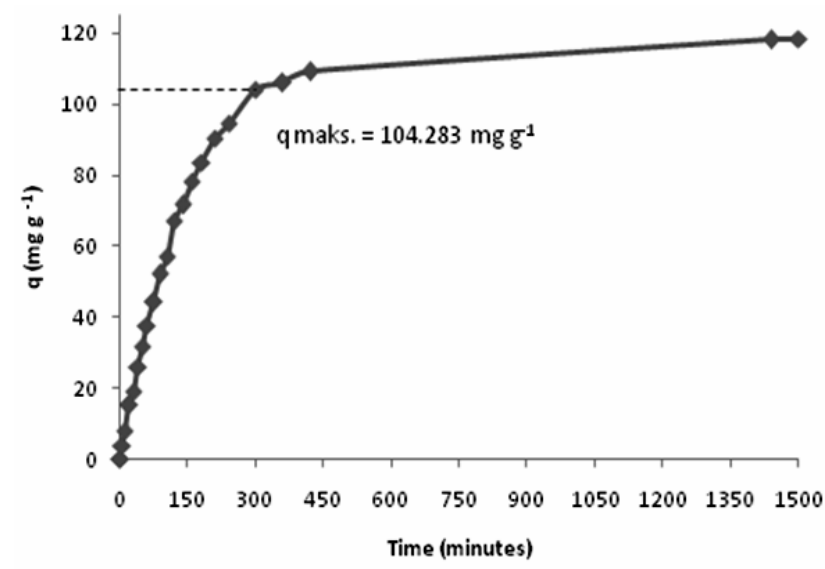

Fig. 9. Effect of contact time on the adsorption of $\mathrm{Cr}(\mathrm{VI})$ ion onto chitosan beads
Fig. 9 shows that the maximum adsorption capacity occurrs at $300 \mathrm{~min}$, where the amount of $\mathrm{Cr}(\mathrm{VI})$ adsorbed is $104.283 \mathrm{mg} \mathrm{g}^{-1}$. Within the interval of $0-300 \mathrm{~min}$, the adsorption of $\mathrm{Cr}(\mathrm{VI})$ occurs quickly due to large availability of empty sites to be occupied by $\mathrm{Cr}(\mathrm{VI})$. Thereafter, the adsorption slowly begins because all active sites are filled with $\mathrm{Cr}(\mathrm{VI})$ ions, and equilibration state is achieved.

\subsection{Adsorption Kinetics}

The kinetics study of $\mathrm{Cr}(\mathrm{VI})$ adsorption on chitosan beads may provide an insight on the adsorption mechanism quantitatively. The reaction order and reaction rate constants can be determined by using the method of fractionation time and Powell plot method. Fractionation time, $t_{\alpha}$, is the time when the concentration $[A]$ is changed into $\alpha$ time of the initial concentration $[A]_{0}$. The value of $\alpha$ is within $0-1$ range. By using the rate equation, $r=k \cdot[A]^{n}$, the value of $t_{\alpha}$ could be determined. If $n=1$; then the value of $t_{\alpha}$ :

$$
t_{\alpha}=-\frac{\ln \alpha}{k_{\alpha}}
$$

When $\mathrm{n} \neq 1 ; t_{\alpha}$ is calculated as following:

$$
t_{\alpha}=\frac{\alpha^{1-n}-1}{(n-1) k_{\alpha}[A]_{0}^{n-1}}
$$

From which the linear equation for $\mathrm{n} \neq 1$ is:

$$
\ln t_{\alpha}=\ln \frac{\alpha^{1-n}-1}{(n-1) k_{\alpha}}-(n-1) \ln [A]_{0}
$$

For examination of the adsorption kinetics, a relaionship between time $t$ and $\mathrm{Cr}(\mathrm{VI})$ ions concentration is plotted in Fig. 10. The longer the contact time, the less amount of $\mathrm{Cr}(\mathrm{VI})$ in the solution.

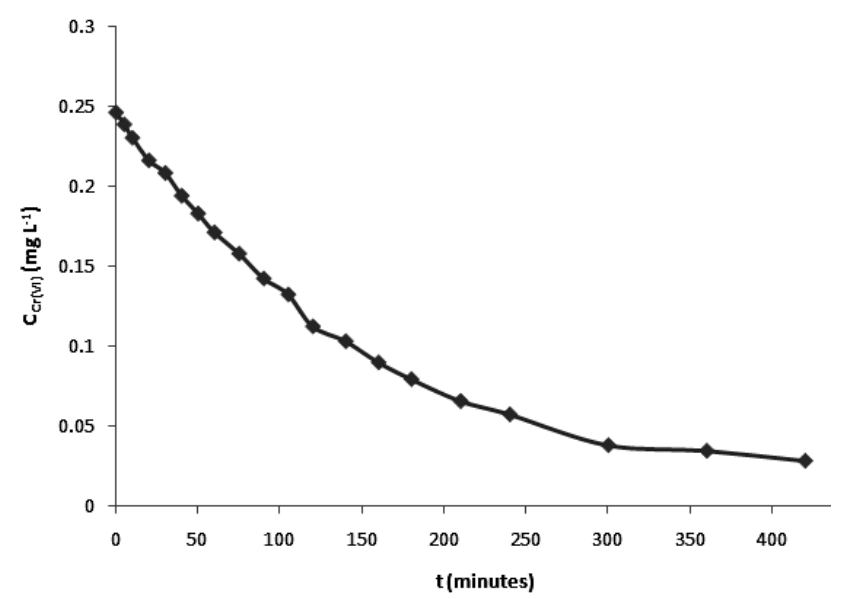

Fig. 10. Relationship between time (min) and remaining concentration of $\mathrm{Cr}(\mathrm{VI})$ in the solution

Fig. 10 may be used to determine the value $t_{\alpha}$ in order to obtain the value of reaction order. If the 
fractionation time is obtained for each concentration of $\mathrm{Cr}(\mathrm{VI})$ at equilibrium (constant), then the value of the reaction order $n$ is of the first order. This result is demonstrated in Fig. 11.

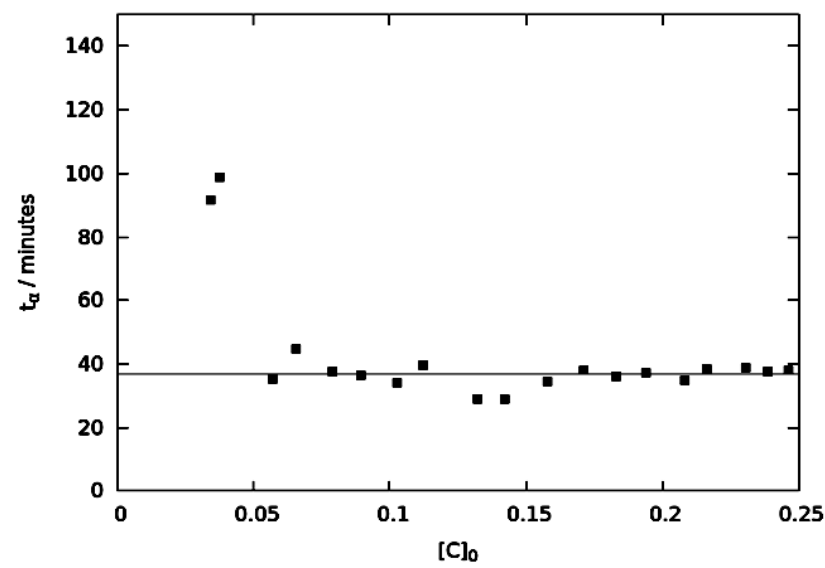

Fig. 11. The relationship of initial concentration of $\mathrm{Cr}(\mathrm{VI})$ adsorbed on the chitosan beads every time $t_{\alpha}(\alpha=0.8)$

Besides this, Powell plot method was also applied. This method is a dimensional shape for determination of the reaction order as a function of the logarithm based on the equation $r=k_{a} \cdot[A]^{n}$. This equation is defined as a dimensionless parameter:

$$
\begin{gathered}
\alpha=\frac{[A]}{[A]_{0}} \text { and } \phi=k_{\alpha}[A]_{0}^{n-1} t_{\alpha} \\
\log \phi=\log k_{\alpha}[A]_{0}^{n-1}+\log t_{\alpha}
\end{gathered}
$$

So, for $\mathrm{n}=1$ :

$$
\ln \frac{[A]}{[A]_{0}}=-k_{\alpha} t \text { is multiplied by }[A]_{0}^{n-1}
$$

Then:

$$
\begin{aligned}
{[A]_{0}^{n-1} \ln \alpha } & =-k_{\alpha} t[A]_{0}^{n-1} \\
\ln \alpha & =\phi
\end{aligned}
$$

For $n \neq 1$ :

$$
\frac{1}{[A]^{n-1}}-\frac{1}{[A]_{0}^{n-1}}=(n-1) k_{\alpha} t
$$

is multiplied by $[A]_{0}^{n-1}$ and then:

$$
\begin{aligned}
& \frac{[A]_{0}^{n-1}}{[A]^{n-1}}-1=(n-1) k_{\alpha} t[A]_{0}^{n-1} \\
& \frac{1}{\alpha^{n-1}}-1=(n-1) \phi \\
& \alpha^{1-n}-1=(n-1) \phi
\end{aligned}
$$

By using the Powell plot method as given in Eq. (11), reaction order could be determined theoretically and experimentally. The determination of the order of $0 ; 1 / 2$; $1 ; 3 / 2 ; 2 ; 5 / 2$; and 3 were theoretically plotted on a curve $\alpha$ vs. $\log \Phi$ (Fig. 12). $\log t$ and $\alpha$ of the experimental data were plotted in the same graph, and we found that the adsorption of $\mathrm{Cr}(\mathrm{VI})$ onto the chitosan beads follows the first order reaction.

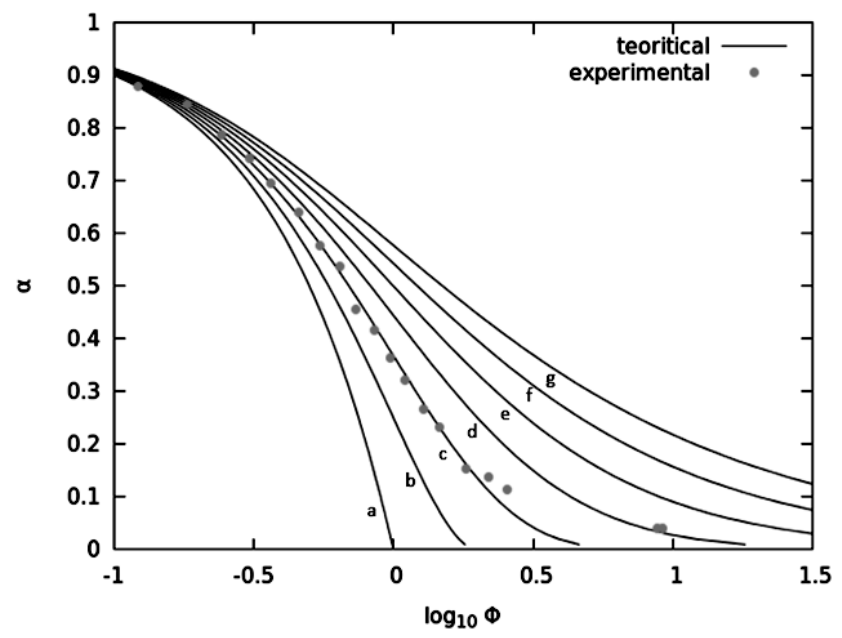

Fig. 12. The reaction order $n$ according to Powell plot method: 0 (a); 1/2 (b); 1 (c); 3/2 (d); 2 (e); 5/2 (f) and 3 (g)

The value of the reaction order indicates that the adsorption process is a physical adsorption (Van Der Waals adsorption). It means that the interaction between $\mathrm{Cr}(\mathrm{VI})$ and chitosan beads occurs just on the surface of the chitosan beads. Physical adsorption does not involve the transfer of electrons and it always maintains the shape of interacted substances. The interactions between $\mathrm{Cr}(\mathrm{VI})$ and chitosan beads are equilibrated and it is possible to conduct desorption at the same temperatures, although the adsorption process occurs slowly because of diffusion.

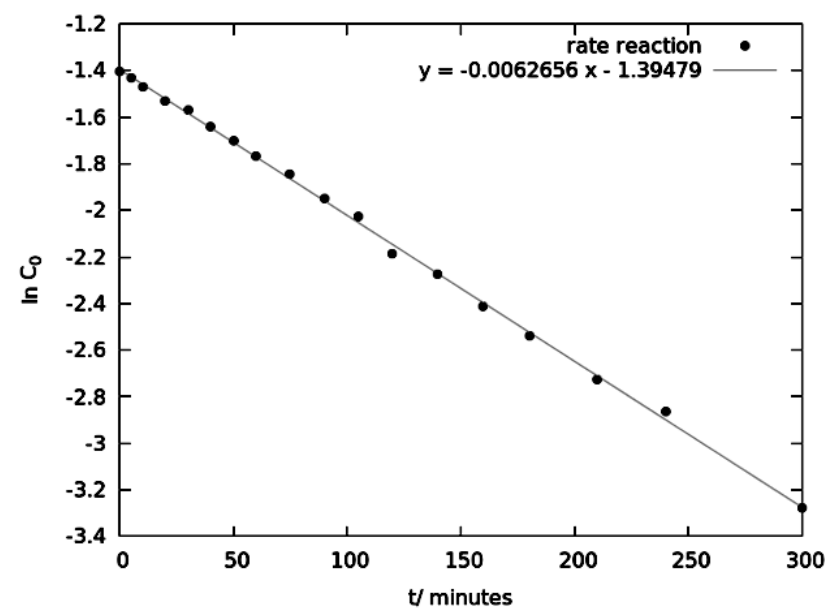

Fig. 13. Graph of the exponential function concentration of $\mathrm{Cr}(\mathrm{VI})$ adsorbed on the chitosan beads per time $t$ 
The adsorption rate constants were determined from the graph $t v s$. the exponential function of the $\mathrm{Cr}(\mathrm{VI})$ concentration (Fig. 13). It is shown that the value of the adsorption rate constant is $6.266 \cdot 10^{-3} \mathrm{~min}^{-1}$. The adsorption rate shows that the adsorption process occurs slowly because the surface area of the chitosan beads is small.

\section{Conclusions}

The manufacture of chitosan beads using TPP could be influenced by the TPP concentration and immersion time between chitosan with TPP, which was in $5 \%$ TPP solution for $3 \mathrm{~h}$ of immersion time, the formed chitosan beads have the largest adsorption capacity. Crosslinking agents are also used to improve the stability of the formed chitosan beads. EGDE is used as a crosslinking agent and has the optimum concentration of $5 \%$. In the adsorption process, $\mathrm{pH}$ of $\mathrm{Cr}(\mathrm{VI})$ solution also plays an important role. If $\mathrm{pH}$ is acidic, the amount of adsorbed $\mathrm{Cr}(\mathrm{VI})$ increases while at the alkaline $\mathrm{pH}-$ decreases. The optimum $\mathrm{pH}$ was found to be 3. By analyzing the adsorption kinetics using fractionation time and Powell plot method, it was found that the adsorption of $\mathrm{Cr}(\mathrm{VI})$ onto the chitosan beads occurs physically (physisorption) and fits the first order reaction.

\section{References}

[1] Jialong Wang C.: Bioresource Technol., 2014, 160, 129.

[2] Ghaee A., Shariaty-Niassar M., Barzin J and Zarghan A.: Appl. Surf. Sci., 2012, 258, 7732.

[3] Muradiye U. and Irfan Ar.: J. Hazard. Mater., 2007, 149, 482.

[4] Malcok E. and Nuhoglu Y.: Chem. Eng. Process., 2007, 46, 1020.

[5] Fu F. and Wang Q.: Environ. Manage., 2011, 92, 407.
[6] Selvi K., Pattabhi S. and Kadirvelu K.: Bioresource Technol., 2001, 80, 87.

[7] Arenas L. et.al.: Colloid surface A., 2007, 297, 240.

[8] Hu X.-J. et.al.: J. Hazard. Mater., 2011, 158, 306.

[9] Mi F.-L., Shyu S.-S., Chen C.-T. and Lai J.-Y., Polymer, 2002, 43, 757.

[10] Lee S.-T., Mi F.-L., Shen Y.-J. and Shyu S.-S.: Polymer, 2001, 42, 1879.

[11] Kamari A., Wan Saime W., Lai Ken L.: Environ. Sci., 2009, 21, 296.

[12] Guibal E.: Pro. Polym. Sci., 2005, 30, 71.

[13] Gotoh T., Matsushima K. and Kikuchi K.: Chemosphere, 2004, $\mathbf{5 5}, 135$.

[14] Wan Ngah. W. and Fatinathan S.: J. Environ. Manage., 2010, 91, 958 .

\section{ПРИГОТУВАННЯ ХІТОЗАНОВИХ ГРАНУЛ З ВИКОРИСТАННЯМ ТРИПОЛІФОСФАТУ І ДІГЛЩЦДІЛОВОГО ЕТЕРУ ЕТИЛЕНГЛІКОЛЮ ЯК ЗШИВАЮЧОГО АГЕНТА ДЛЯ АДСОРБЦЇ̈ Cr(VI)}

Анотація. 3 використанням триполіфосфату (ТПФ) та діглічиділового етеру етиленгліколю (ДГЕЕ) як зшиваючого агента приготовлено твердофазний матеріал на основі модифікованого хітозану. Досліджено його адсорбуючу здатність відносно хрому(VI). Показано, щзо за допомогою ТПФ пластівець хітозану може бути сформований в гранулу, а його хімічна стабільність покрашується при використанні ДГЕЕ як зииваючого агента. Для визначення оптимальних умов вивчено вплив таких чинників, як склад $i$ час занурення. Характеристику отриманого продукту визначено за допомогою сканувального електронної мікроскопії та Фур“є-спектроскопії. Здатність модифікованого хітозану адсорбувати $\mathrm{Cr}(\mathrm{VI})$ підтверджено результатами досліджень адсорбиійної здатності $i$ кінетичними дослідженнями. Визначено, щя адсорбиійна здатність модифікованого хітозану становить 104.283 мг/2 при $\mathrm{pH}=3$, а адсорбиія $\epsilon$ реакцією периого порядку, яка припускає йонообмінний механізм.

Ключові слова: хітозанові гранули, Cr(VI), триполіфосфат, адсорбиійна здатність, кінетика адсорбиії. 
